\title{
EFEKTIVITAS NPK GROWER DAN POC BONGGOL PISANG PADA PERTUMBUHAN BIBIT TANAMAN PISANG KEPOK (Musa paradisiaca) DENGAN TEKNIK BELAHAN BONGGOL
}

\section{The Effectiveness of NPK Grower and Banana Humps Liquid Organic Fertilizer on the Growth of Kepok Banana Seedling (Musa paradisiaca) with Humps Technique}

\author{
T. Rosmawaty ${ }^{1}$, Raisa Baharuddin ${ }^{1}$, Hendro Priono $^{2}$ \\ ${ }^{1}$ Dosen Prodi Agroteknologi, Universitas Islam Riau \\ ${ }^{2}$ Mahasiswa Prodi Agroteknologi, Universitas Islam Riau \\ email: t.rosmawaty@agr.uir.ac.id \\ [Diterima: November 2021; Disetujui: Desember 2021]
}

\begin{abstract}
The development of kepok bananas in Indonesia generally uses banana sapling, but this technique has weaknesses such as low uniformity and takes a long time. So, it is necessary to get the latest techniques such as the technique of splitting humps which is easier and cheaper. In addition, its development requires the balanced fertilization techniques using inorganic and organic fertilizers. This study aims to determine the effect of interaction and the main effect of NPK Grower and banana humps liquid organic fertilizer (LOF) on the growth of kepok banana seedlings (Musa paradisiaca) by using the splitting humps. This research was carried out at the Experimental farm of the Faculty of Agriculture, Riau Islamic University, Pekanbaru City. The study was conducted from March to May 2021. The research design used a completely randomized design (CRD) with two factors. The first factor was the concentration of NPK Grower $(G)$, which consisted of 4 levels, which were $0 \mathrm{~g} / \mathrm{plant}$, $15 \mathrm{~g} /$ plant, $30 \mathrm{~g} / \mathrm{plant}$, and $45 \mathrm{~g} /$ plant. The second factor was LOF banana humps (P), consisting of 4 levels, namely $0 \%, 15 \%, 30 \%$, and $45 \%$ which consisted of 3 replications. The parameters observed were the percentage of growth, budding time, plant height, number of leaves, stem girth, longest leaf length, and widest leaf width. The data were statistically analyzed and continued with the honest significant difference test (HSD) at the 5\% level. The results showed that there was a significant interaction between NPK Grower and banana humps LOF on the parameters of plant height, number of leaves, stem girth, longest leaf length, and widest leaf width. The best treatment was found in NPK Grower with a dose of $45 \mathrm{~g}$ /plant combined with a concentration of LOF banana humps of $300 \mathrm{ml} / \mathrm{lair}$.
\end{abstract}

Keywords: Banana Humps LOF, Kepok Banana, NPK Grower, Splitting Humps.

\begin{abstract}
Pengembangan pisang kepok di Indonesia umumnya dilakukan dengan teknik anakan, namun teknik tersebut memiliki kelemahan seperti keseragaman yang rendah dan waktu yang lama. Sehingga perlu adanya teknik terbaru seperti teknik belahan bonggol yang lebih mudah dan murah. Selain itu, dalam pengembangannya diperlukan teknik pemupukan yang berimbang dengan menggunakan pupuk anorganik dan organik. Penelitian ini bertujuan untuk mengetahui pengaruh interaksi maupun pengaruh utama NPK Grower dan POC bonggol pisang terhadap pertumbuhan bibit tanaman pisang kepok (Musa paradisiaca) dengan teknik belahan bonggol. Penelitian ini telah dilaksanakan di Kebun Percobaan Fakultas Pertanian Universitas Islam Riau, Kota Pekanbaru. Penelitian dilaksanakan pada bulan Maret sampai Mei 2021. Rancangan penelitian menggunakan Rancangan Acak Lengkap (RAL) dengan dua faktor. Faktor pertama adalah Konsentrasi NPK Grower (P), terdiri dari 4 taraf yaitu 0 g/tanaman, $15 \mathrm{~g} /$ tanaman, $30 \mathrm{~g} / \mathrm{tanaman}$, dan $45 \mathrm{~g} / \mathrm{tanaman}$. Faktor kedua adalah POC bonggol pisang (K), terdiri dari 4 taraf yaitu 0\%, 15\%, 30\% dan 45\% yang terdiri atas 3 ulangan. Parameter yang diamati adalah persentase tumbuh, umur muncul tunas, tinggi tanaman, jumlah daun, lilit batang, panjang daun terpanjang dan lebar daun terlebar. Data dianalisis secara statistik dan dilanjutkan uji beda nyata jujur (BNJ) pada taraf 5\%. Hasil penelitian menunjukan bahwa terdapat interaksi nyata antara NPK Grower dan POC bonggol pisang pada parameter tinggi tanaman, jumlah daun, lilit
\end{abstract}


batang, panjang daun terpanjang dan lebar daun terlebar. Perlakuan terbaik terdapat pada NPK Grower dengan dosis $45 \mathrm{~g} /$ tanaman yang dikombinasikan dengan konsentrasi POC bonggol pisang $300 \mathrm{ml} / \mathrm{lair}$.

Kata kunci: Belahan Bonggol, NPK Grower, Pisang Kepok, POC Bonggol Pisang.

\section{PENDAHULUAN}

Pisang merupakan buah yang paling banyak diproduksi dan dikonsumsi di Indonesia. Berdasarkan data BPS (2018), menyebutkan bahwa total produksi pisang di Indonesia pada tahun 2018 mencapai 7.264.383 ton dengan peningkatan sebesar 1.41 $\%$ dari tahun sebelumnya. Kemudian total produksi pisang di provinsi Riau pada tahun 2017 mencapai 38.809 ton dengan peningkatan sebesar $54.23 \%$ dari tahun sebelumnya. Banyaknya produksi pisang tersebut menjadikan Indonesia sebagai sentra produsen pisang dan memenuhi kebutuhan 50\% pisang di Asia.

Dalam pengembangannya, saat ini dilakukan selama ini dengan cara pemisahan anakan. Pengembangan bibit pisang melalui pemisahan anakan dapat memakan waktu yang cukup lama dan tingkat keseragamannya rendah. Sehingga perlu teknik lain dalam pengembangan bibit pisang kepok seperti teknik belahan bonggol. Asmarawati dan Bahrum (2011), menyatakan bahwa teknik belahan bonggol adalah perbanyakan tanaman pisang yang memanfaatkan bonggol pisang yang sebelumnya dibelah terlebih dahulu sesuai mata tunasnya. Kelebihan teknik belahan bonggol yaitu biaya yang digunakan relatif murah dan tidak membutuhkan keahlian khusus.

Salah satu cara untuk meningkatkan ketersediaan bibit pisang kepok melalui teknik belahan bonggol yaitu dengan pemupukan berimbang dengan pemberian pupuk anorganik maupun pupuk organik. Pupuk anorganik yang sering digunakan petani yaitu pupuk majemuk NPK Grower. NPK Grower mengandung unsur hara $15 \% \mathrm{~N}, 9 \% \quad \mathrm{P}_{2} \mathrm{O}_{5}, 20 \% \mathrm{~K}_{2} \mathrm{O}$ dan beberapa unsur hara mikro lainnya yang dibutuhkan tanaman baik dalam pertumbuhan vegetatif maupun generatif tanaman (Anonim, 2015).

Pemberian pupuk anorganik harus diimbangi dengan pemberian pupuk organik. Bonggol pisang selain digunakan sebagai bahan perbanyakan vegetatif tanaman pisang dapat dimanfaatkan juga menjadi pupuk organik cair. Di dalam bonggol pisang terkandung $\mathrm{C} / \mathrm{N}$ 2,2\%, Fe 0,09 ppm, dan $\mathrm{Mg}$
800 ppm (Suhastyo, 2011). Selain itu, bonggol pisang memiliki zat pengatur tumbuh yaitu sitokinin (Lindung, 2014). Pupuk organik cair (POC) yang dihasilkan dari bonggol pisang berperan dalam peningkatan pengikatan ionion seperti $\mathrm{Al}, \mathrm{Fe}$ dan $\mathrm{Ca}$ sehingga dapat membantu ketersediaan fosfor (P) dalam tanah (Setianingsih, 2009). Penelitian ini bertujuan untuk mengetahui efektivitas NPK Grower dan POC bonggol pisang pada pertumbuhan bibit tanaman pisang kepok dengan teknik belahan bonggol.

\section{METODE PENELITIAN}

Penelitian ini dilaksanakan di Kebun Percobaan Fakultas Pertanian Universitas Islam Riau, Kecamatan Bukit Raya, Kota Pekanbaru. Penelitian dilakukan selama 3 bulan dari bulan Maret sampai Mei 2021 .

Bahan yang digunakan diantaranya NPK Grower, bonggol pisang kepok, EM4, sekam bakar, tali raffia, polybag $(35 \times 40 \mathrm{~cm})$, seng plat, kayu, cat, spanduk penelitian, kaleng, bambu, dan paku. Alat yang digunakan yaitu: penggaris, meteran, jangka sorong, gunting, cangkul, pisau, garu, kuas, ember, gembor, palu, hand sprayer, kamera, timbangan, gelas ukur $(1000 \mathrm{ml})$, saringan, gayung dan alat tulis.

Rancangan yang digunakan adalah Rancangan Acak Lengkap (RAL) faktorial. Faktor pertama adalah dosis NPK Grower (G) yang terdiri 4 taraf perlakuan dan faktor kedua adalah konsentrasi POC Bonggol Pisang (P) yang terdiri dari 4 taraf. Setiap perlakuan diulang sebanyak 3 kali.

Faktor dosis pupuk NPK Grower (G), terdiri dari 4 taraf yaitu:

G0: 0 (Tanpa perlakuan)

G1: $15 \mathrm{~g} /$ tanaman

G2: $30 \mathrm{~g} /$ tanaman

G3: $45 \mathrm{~g} /$ tanaman

Faktor konsentrasi POC Bonggol Pisang (P), terdiri dari 4 taraf yaitu:

P0: 0 (Tanpa perlakuan)

P1: $15 \%$ (150 ml/l air)

P2: $30 \%$ (300 ml/l air)

P3: $45 \%$ (450 $\mathrm{ml} / \mathrm{l}$ air)

Parameter yang diamati meliputi, persentase tumbuh (\%), umur muncul tunas, 
tinggi tanaman, jumlah daun, lilit batang,panjang daun terpanjang dan lebar daun terpanjang. Data pengamatan dari masingmasing perlakuan dianalisis secara statistik dengan menggunakan analisis sidik ragam (ANOVA). Apabila F-hitung lebih besar dari F tabel, maka dilanjutkan dengan uji lanjut Beda Nyata Jujur (BNJ) pada taraf 5\%.

\section{HASIL DAN PEMBAHASAN}

\section{Persentase Tumbuh Tunas}

Hasil pengamatan persentase tumbuh tunas tanaman pisang setelah dilakukan analisis ragam menunjukkan bahwa secara interaksi tidak memberikan pengaruh yang nyata, namun pengaruh utama pemberian NPK Grower dan POC bonggol pisang memberikan pengaruh nyata terhadap persentase tumbuh tunas bibit pisang (Tabel 1).

Pada pengaruh utama NPK Grower, dosis 30 dan $45 \mathrm{~g} / \operatorname{tanaman}$ (G2 dan G3) memberikan persentase tumbuh tertinggi yaitu 91.67\% dan berbeda nyata dengan perlakuan lainnya. Perlakuan Dosis POC bonggol pisang 300 dan $450 \mathrm{ml} / 1$ air (P2 dan P3) dengan memberikan pengaruh yang nyata terhadap persentase tumbuh yaitu 95.83 dan $93.75 \%$, dan berbeda nyata dengan perlakuan lainnya.

$$
\text { Keuntungan yang diperoleh }
$$
menggunakan pupuk NPK Grower dengan perlakuan $30 \mathrm{~g} /$ tanaman dan $45 \mathrm{~g} /$ tanaman $(\mathrm{G} 2$ dan G3) adalah mampu mencukupi kebutuhan unsur hara terutama $\mathrm{N}$ dan $\mathrm{P}$ pada tanaman sehingga pertumbuhan dan perkembangan tanaman dapat berjalan dengan baik. Jumlah unsur nitrogen $(\mathrm{N})$ sangat berpengaruh nyata terhadap daya berkecambah (Komalasari dan Koes, 2009) dan peningkatan perlakuan pemupukan fosfat $(\mathrm{P})$ menyebabkan peningkatan nilai kecepatan tumbuh (Lesilolo, 2012).

Tabel 1. Rata-rata persentase tumbuh tunas bibit pisang dengan perlakuan NPK Grower dan POC bonggol pisang.

\begin{tabular}{|c|c|c|c|c|c|}
\hline \multirow{2}{*}{$\begin{array}{l}\text { NPK Grower } \\
(\mathrm{g} / \operatorname{tanaman})(\mathrm{G})\end{array}$} & \multicolumn{4}{|c|}{ POC Bonggol Pisang (ml/l air) (P) } & \multirow{2}{*}{ Rerata } \\
\hline & $0(\mathrm{P} 0)$ & $150(\mathrm{P} 1)$ & $300(\mathrm{P} 2)$ & $450(\mathrm{P} 3)$ & \\
\hline $0(\mathrm{G} 0)$ & 75,00 & 75,00 & 83,33 & 83,33 & $79,17 \mathrm{~b}$ \\
\hline 15 (G1) & 83,33 & 83,33 & 91,67 & 100,00 & $89,58 \mathrm{~b}$ \\
\hline $30(\mathrm{G} 2)$ & 83,33 & 83,33 & 100,00 & 100,00 & $91,67 \mathrm{a}$ \\
\hline $45(\mathrm{G} 3)$ & 83,33 & 83,33 & 100,00 & 100,00 & $91,67 \mathrm{a}$ \\
\hline Rerata & $81,25 \mathrm{~b}$ & $81,25 \mathrm{~b}$ & $93,75 \mathrm{a}$ & $95,83 \mathrm{a}$ & \\
\hline
\end{tabular}

Keterangan: angka-angka yang diikuti huruf yang tidak sama pada baris dan kolom yang sama berbeda nyata menurut BNJ pada taraf $5 \%$.

Pupuk Organik Cair (POC) bonggol pisang selain memiliki kandungan unsur hara, juga memiliki hormon tumbuh berupa sitokonin dan giberelin. Hormon tumbuh sitokinin memiliki peran dalam pembelahan sel tanaman kemudian didukung oleh giberelin yang berperan dalam pembesaran sel tanaman sehingga tanaman akan cepat tumbuh dan berkembang dengan baik. Hal ini sependapat dengan Lindung (2014) yang menyatakan bahwa di dalam bonggol pisang terdapat zat pengatur tumbuh yaitu sitokinin. Zat pengatur tumbuh giberelin dan sitokinin merupakan zat pengatur tumbuh yang merangsang dan mempercepat pertumbuhan.

\section{Umur Muncul Tunas}

Hasil pengamatan umur muncul tunas setelah dilakukan analisis ragam menunjukkan bahwa secara interaksi tidak memberikan pengaruh yang nyata, pada pengaruh utama pemberian NPK Grower dan POC bonggol pisang memberikan pengaruh nyata terhadap umur muncul tunas tanaman pisang. Rata-rata hasil pengamatan umur tunas tanaman pisang dilakukan uji BNJ pada taraf 5\% dapat dilihat pada Tabel 2.

Data pada Tabel 2 menunjukan bahwa pengaruh utama NPK Grower memberikan pengaruh yang nyata terhadap umur muncul tunas tanaman pisang. Perlakuan NPK Grower $45 \mathrm{~g} / \operatorname{tanaman}$ (G3) menghasilkan umur muncul tunas yang lebih cepat yaitu 18,08 hst namun tidak berbeda nyata dengan perlakuan NPK Grower dosis 15 dan $30 \mathrm{~g} / \operatorname{tanaman}$ (G1 dan G2). Lebih cepatnya umur muncul tunas pada bibit pisang yang diberikan pupuk NPK Grower dikarenakan terpenuhinya unsur hara yang dibutuhkan oleh tanaman pisang tersebut. NPK grower memiliki kandungan N 15\%, $\mathrm{P}_{2} \mathrm{O}_{5} 9 \%, \mathrm{~K}_{2} \mathrm{O} 20 \%$ yang sangat menunjang pertumbuhan tanaman. 
Pertumbuhan tunas dipengaruhi oleh akar, karena akar adalah bagian tanaman yang menyerap unsur hara. Pertumbuhan akar yang baik diikuti juga dengan pertumbuhan tunas yang baik (Yunita, 2011). Unsur hara P sangat diperlukan untuk pertumbuhan akar selama tahap awal pertumbuhan tanaman (Setyorini, $\mathrm{dkk}, 2020$ ). Akar yang terbentuk tersebut akan mensintesis sitokinin dan mentranslokasikan sitokinin tersebut ke pucuk dan memacu pembelahan sel, sehingga terjadi pemecahan dormansi pada mata tunas.

Tabel 2. Rata-rata umur muncul tunas (HST) dengan perlakuan NPK Grower dan POC bonggol pisang.

\begin{tabular}{lccccc}
\hline \multirow{2}{*}{$\begin{array}{c}\text { NPK Grower } \\
\text { (g/tanaman) }(\mathrm{G})\end{array}$} & $0(\mathrm{P} 0)$ & $150(\mathrm{P} 1)$ & $300(\mathrm{P} 2)$ & \multirow{2}{*}{ Rerata } \\
\cline { 2 - 5 } 0 (G0) & 20,33 & 19,33 & 20,00 & $190(\mathrm{P} 3)$ & \\
$15(\mathrm{G} 1)$ & 20,67 & 18,67 & 18,67 & 17,33 & $18,83 \mathrm{~b}$ \\
$30(\mathrm{G} 2)$ & 19,33 & 19,33 & 17,33 & 18,33 & $18,58 \mathrm{ab}$ \\
45 (G3) & 19,00 & 18,67 & 17,33 & 17,33 & $18,08 \mathrm{a}$ \\
\hline Rerata & $19,83 \mathrm{~b}$ & $19,00 \mathrm{ab}$ & $18,33 \mathrm{a}$ & $18,17 \mathrm{a}$ & \\
\hline \multicolumn{5}{c}{$\mathrm{KK}=6,98 \%$} & BNJ\&K=1,46 \\
\hline
\end{tabular}

Keterangan: angka-angka yang diikuti huruf yang tidak sama pada baris dan kolom yang sama berbeda nyata menurut BNJ pada taraf $5 \%$.

Selanjutnya untuk pengaruh utama POC Bonggol pisang konsentrasi $450 \mathrm{ml} / \mathrm{l}(\mathrm{P} 3)$ memberikan umur muncul tunas lebih cepat yaitu 18,17 hst dan tidak berbeda nyata dengan perlakuan P2 dan P1 namun berbeda nyata dengan perlakuan P0. POC Bonggol pisang berperan dalam memperbaiki sifat fisik, kimia dan biologis tanah sehingga tanah menjadi subur. Menurut Sumarni, dkk (2010) pemberian bahan organik merupakan salah satu cara untuk memperbaiki sifat fisik tanah. Bahan organik dapat memperbaiki struktur tanah, meningkatkan kapasitas menahan air, pori aerasi, dan laju infiltrasi, serta memudahkan penetrasi akar, sehingga penyerapan unsur hara menjadi optimal. Selain itu, kandungan unsur hara pada POC bonggol pisang seperti $\mathrm{N} \mathrm{0,88 \% ,} \mathrm{P2O5} \mathrm{0,11 \%} \mathrm{dan}$ $\mathrm{K} 2 \mathrm{O} 3 \quad 1,23 \%$ dapat membantu dalam pertumbuhan tunas tanaman pisang.

\section{Tinggi Tanaman}

Hasil pengamatan tinggi tanaman setelah dilakukan analisis ragam menunjukkan bahwa secara interaksi maupun pengaruh utama pemberian NPK Gower dan POC bonggol pisang memberikan pengaruh yang nyata terhadap tinggi tanaman pisang. Ratarata hasil pengamatan umur tunas tanaman pisang dilakukan uji BNJ pada taraf 5\% dapat dilihat pada Tabel 3.

Dari data pada Tabel 3 menunjukkan bahwa secara interaksi dan pengaruh utama NPK Gower dan POC bonggol pisang memberikan pengaruh yang nyata terhadap tinggi tanaman. Pertumbuhan tercepat dengan dengan dosis NPK Grower $45 \mathrm{~g} /$ tanaman dan konsentrasi POC bonggol pisang yaitu $450 \mathrm{ml} / 1$ air (G3P3), tidak berbeda nyata dengan G3P2, G2P3, G2P2 dan berbeda nyata dengan perlakuan lainya.

Tabel 3. Rata-rata tinggi tanaman $(\mathrm{cm})$ dengan perlakuan NPK Gower dan POC bonggol pisang pada umur 73 hst.

\begin{tabular}{|c|c|c|c|c|c|}
\hline \multirow{2}{*}{$\begin{array}{l}\text { NPK Grower } \\
(\mathrm{g} / \mathrm{tanaman})(\mathrm{G})\end{array}$} & \multicolumn{4}{|c|}{ POC Bonggol Pisang (ml/l air) (P) } & \multirow[b]{2}{*}{ Rerata } \\
\hline & $0(\mathrm{P} 0)$ & $150(\mathrm{P} 1)$ & $300(\mathrm{P} 2)$ & 450 (P3) & \\
\hline 0 (G0) & $22,83 \mathrm{e}$ & $25,50 \mathrm{de}$ & $27,00 \mathrm{de}$ & $28,50 \mathrm{de}$ & $25,96 \mathrm{c}$ \\
\hline 15 (G1) & $25,67 \mathrm{de}$ & $28,50 \mathrm{de}$ & $30,50 \mathrm{cde}$ & $29,33 \mathrm{de}$ & $28,50 \mathrm{~b}$ \\
\hline $30(\mathrm{G} 2)$ & $26,33 \mathrm{de}$ & $31,33 \mathrm{~b}-\mathrm{e}$ & $38,67 \mathrm{abc}$ & $39,83 \mathrm{ab}$ & $34,04 \mathrm{a}$ \\
\hline $45(\mathrm{G} 3)$ & $27,17 \mathrm{de}$ & $32,83 \mathrm{bcd}$ & $40,33 \mathrm{ab}$ & $42,50 \mathrm{a}$ & $35,71 \mathrm{a}$ \\
\hline Rerata & $25,50 \mathrm{~b}$ & $29,54 \mathrm{~b}$ & $34,13 \mathrm{a}$ & $35,04 \mathrm{a}$ & \\
\hline
\end{tabular}

Keterangan: angka-angka yang diikuti huruf yang tidak sama pada baris dan kolom yang sama berbeda nyata menurut BNJ pada taraf $5 \%$.

Menurut Kusumawati (2015) bahan organik mengandung materi organik digunakan untuk memperbaiki sifat fisika, kimia, dan biologi tanah. Sehingga pertumbuhan dan perkembangan akar tanaman lebih cepat sehingga penyerapan hara dalam tanah akan maksimal. Selain itu, POC bonggol pisang juga memiliki kandungan $\mathrm{N}, \mathrm{P}$ dan $\mathrm{K}$. Unsur $\mathrm{N}$ 
yang terdapat di dalam bonggol pisang tersedia dalam bentuk ion amonium dan ion nitrat yang langsung dapat diserap oleh tanaman. Nitrogen berperan penting bagi tanaman karena sebagai bahan baku pembentukan asam amino untuk menyusun protein, asam nukleat, dan klorofil bagi tanaman. Menurut Setyorini (2015), nitrogen berfungsi untuk meningkatkan klorofil tanaman sehingga proses fotosintesis meningkat dan mempercepat peningkatan tinggi tanaman. Hal ini terlihat pada hasil penelitian menunjukkan bahwa semakin tinggi konsentrasi yang diberikan maka maka tinggi tanamannya lebih tinggi juga.

Selain itu pertumbuhan vegetatif tanaman juga didukung oleh unsur hara lainnya yang didapatkan dari pemupukan oleh NPK
Grower seperti unsur $\mathrm{P}$, yang memiliki peran dalam pembelahan dan perpanjangan sel sehingga mendukung unsur $\mathrm{N}$ dalam pertumbuhan vegetatif tanaman. Unsur kalium berperan dalam pengangkutan hasil fotosintesis dari daun melalui floem ke seluruh bagian tanaman (Munawar, 2011).

\section{Jumlah Daun (helai)}

Hasil pengamatan jumlah daun tanaman pisang setelah dilakukan analisis ragam menunjukkan bahwa secara interaksi dan pengaruh utama pemberian NPK Grower dan POC bonggol pisang memberikan pengaruh nyata terhadap jumlah daun tanaman pisang. Rata-rata hasil pengamatan jumlah daun tanaman pisang setelah dilakukan uji BNJ pada taraf 5\% dapat dilihat pada Tabel 4 .

Tabel 4. Rata-rata jumlah daun (helai) dengan perlakuan NPK Grower dan POC bonggol pisang

\begin{tabular}{clcccc}
\hline \multirow{2}{*}{$\begin{array}{c}\text { NPK Grower } \\
\text { (g/tanaman) }(\mathrm{G})\end{array}$} & $0(\mathrm{P} 0)$ & $150(\mathrm{P} 1)$ & $300(\mathrm{P} 2)$ & \multirow{2}{*}{ Rerata } \\
\cline { 2 - 5 } $0(\mathrm{G} 0)$ & $5,17 \mathrm{f}$ & $5,33 \mathrm{f}$ & $5,67 \mathrm{ef}$ & $6,17 \mathrm{c}-\mathrm{f}$ & \\
$15(\mathrm{G} 1)$ & $5,50 \mathrm{ef}$ & $6,17 \mathrm{c}-\mathrm{f}$ & $7,33 \mathrm{a}-\mathrm{d}$ & $7,50 \mathrm{abc}$ & $6,63 \mathrm{~b}$ \\
$30(\mathrm{G} 2)$ & $6,00 \mathrm{def}$ & $6,83 \mathrm{~b}-\mathrm{e}$ & $7,50 \mathrm{abc}$ & $7,67 \mathrm{ab}$ & $7,00 \mathrm{ab}$ \\
$45(\mathrm{G} 3)$ & $6,83 \mathrm{~b}-\mathrm{e}$ & $6,00 \mathrm{def}$ & $7,83 \mathrm{ab}$ & $8,50 \mathrm{a}$ & $7,29 \mathrm{a}$ \\
\hline Rerata & $5,88 \mathrm{~b}$ & $6,08 \mathrm{~b}$ & $7,08 \mathrm{a}$ & $7,46 \mathrm{a}$ & \\
\hline \multicolumn{7}{c}{$\mathrm{KK}=7,39 \%$} & BNJ P\&K=0,54 & BNJ PK=1,48 \\
\hline
\end{tabular}

Keterangan: angka-angka yang diikuti huruf yang tidak sama pada baris dan kolom yang sama berbeda nyata menurut $\mathrm{BNJ}$ pada taraf $5 \%$.

Data pada Tabel 4 menunjukkan bahwa secara interaksi dan pengaruh utama pemberian NPK Grower dan POC bonggol pisang memberikan pengaruh nyata terhadap jumlah daun tanaman pisang. Perlakuan NPK Grower $45 \mathrm{~g} /$ tanaman dan POC bonggol pisang $450 \mathrm{ml} / \mathrm{l}$ (G3P3) memberikan jumlah daun terbanyak yaitu 8,50 helai, tidak berbeda nyata dengan G3P2, G2P3, G2P2, G1P3 dan G1P2, namun berbeda nyata dengan perlakuan lainnya.

Perlakuan dosis NPK Grower 3045g/tanaman (G2-G3) dan POC bonggol pisang dengan konsentrasi 300-450 m/l air (P2P3) nyata memberikan jumlah daun yang lebih banyak dari perlakuan lainnya. Hal ini disebabkan perlakuan NPK Grower dan POC bonggol pisang mampu mencukupi kebutuhan nutrisi bagi bibit pisang sehingga pertumbuhan jumlah daun tanaman meningkat. Kandungan nitrogen dalam NPK Grower dan POC bonggol pisang dapat mempercepat pertumbuhan tunas daun, sehingga mendorong proses fotosintesis. Senyawa hasil fotosintesis disimpan dalam bentuk senyawa organik kemudian dilepaskan dalam bentuk ATP untuk pertumbuhan tanaman (Suhastyo, 2011).

Buntoro dkk., (2014) menyatakan bahwa daun berperan dalam menangkap cahaya dan merupakan tempat terjadinya fotosintesis. Perkembangan jumlah daun juga mempengaruhi perkembangan tanaman. Semakin banyak daun berarti semakin banyak cahaya yang dapat ditangkap, sehingga proses fotosintesis akan meningkatkan proses fotosintesis tanaman, sehingga mempengaruhi hasil yang diperoleh.

\section{Lilit Batang}

Hasil pengamatan lilit batang tanaman pisang setelah dilakukan analisis ragam menunjukkan bahwa secara interaksi maupun faktor utama NPK Grower dan POC Bonggol pisang memberikan pengaruh nyata terhadap lilit batang tanaman pisang. Rata-rata hasil pengamatan lilit batang tanaman pisang setelah dilakukan uji BNJ pada taraf 5\% dapat dilihat pada Tabel 5 .

Data pada Tabel 5 menunjukan pada perlakuan NPK Grower 45g/plot dan POC 
Bonggol pisang $450 \mathrm{ml} / \mathrm{l}$ (G3P3) dengan lilit batang tanaman 10,67 cm. Perlakuan G3P3 tidak berbeda nyata dengan perlakuan G3P2, G2P3, G2P2, G1P2, G1P1 dan G3P0 namun berbeda nyata dengan perlakuan lainnya.

Pada perlakuan NPK Grower dosis 30 dan $45 \mathrm{~g} /$ tanaman dengan konsentrasi POC 300 $\mathrm{ml} / \mathrm{lair}$ dan $450 \mathrm{ml} / \mathrm{lair}$ dinilai mampu mencukupi kebutuhan unsur hara untuk menghasilkan lilit batang yang lebih besar dibandingkan dengan perlakuan lainnya. Pada Tabel 3 terlihat bahwa semakin tinggi dosis NPK Grower dan POC batang pisang maka semakin besar lilit batang bibit pisang tersebut. Hasil ini menunjukkan bahwa unsur hara dalam NPK Grower dan POC batang pisang berperan penting dalam pembelahan jaringan tanaman terutama pada jaringan batang bibit pisang.

Unsur hara N, P, K merupakan unsur hara makro yang banyak diserap tanaman terutama pada fase vegetatif (Puspadewi dkk, 2016). Laginda (2017) menyatakan POC batang pisang memiliki kandungan fosfor sebanyak $32 \%$ dimana berperan dalam pembentukan akar muda dan dapat memperkuat berdirinya tanaman. Wahida dan Suryaningsih (2016), menjelaskan bahwa unsur $\mathrm{P}$ berperan dalam proses fotosintesis kemudian karbohidrat yang dihasilkan akan disintesis dengan unsur $\mathrm{N}$ dan $\mathrm{P}$ menjadi protein. Dengan demikian, pembentukan sel, jaringan dan organ akan menjadi pesat sehingga pertumbuhan tanaman akan cepat.

Tabel 5. Rata-rata lilit batang bibit pisang dengan perlakuan POC Bonggol pisang dan NPK Grower $(\mathrm{cm})$

\begin{tabular}{|c|c|c|c|c|c|}
\hline \multirow{2}{*}{$\begin{array}{c}\text { NPK Grower } \\
(\mathrm{g} / \text { tanaman })(\mathrm{G})\end{array}$} & \multicolumn{4}{|c|}{ POC Bonggol Pisang (ml/l air) (P) } & \multirow{2}{*}{ Rerata } \\
\hline & $0(\mathrm{P} 0)$ & $150(\mathrm{P} 1)$ & $300(\mathrm{P} 2)$ & $450(\mathrm{P} 3)$ & \\
\hline $0(\mathrm{G} 0)$ & $6,00 \mathrm{e}$ & $7,00 \mathrm{de}$ & $7,83 \mathrm{~b}-\mathrm{e}$ & 7,33 de & $7,04 \mathrm{c}$ \\
\hline $15(\mathrm{G} 1)$ & 7,33 de & 8,17 a-e & 8,67 a-d & 7,67 cde & $7,96 \mathrm{bc}$ \\
\hline $30(\mathrm{G} 2)$ & $7,83 \mathrm{~b}-\mathrm{e}$ & $7,83 \mathrm{~b}-\mathrm{e}$ & 8,33 a-e & $10,17 \mathrm{abc}$ & $8,54 \mathrm{ab}$ \\
\hline $45(\mathrm{G} 3)$ & 8,17 a-e & $8,00 \mathrm{~b}-\mathrm{e}$ & $10,33 \mathrm{ab}$ & $10,67 \mathrm{a}$ & $9,29 \mathrm{a}$ \\
\hline Rerata & $5,88 \mathrm{~b}$ & $6,08 \mathrm{~b}$ & $7,08 \mathrm{a}$ & $7,46 \mathrm{a}$ & \\
\hline \multicolumn{6}{|c|}{$\mathrm{KK}=10,37 \% \quad$ BNJ P\&K=0,94 BNJ PK 2,56 } \\
\hline
\end{tabular}

Keterangan: angka-angka yang diikuti huruf yang tidak sama pada baris dan kolom yang sama berbeda nyata menurut BNJ pada taraf $5 \%$.

Selain itu penambahan unsur $\mathrm{K}$ yang berasal dari NPK Grower berfungsi untuk meningkatkan kadar sklerenkim pada batang. Sklerenkim berfungsi untuk memberi penebalan dan kekuatan pada jaringan batang sehingga tanaman tidak mudah rebah. Satria, dkk (2015) juga menyatakan bahwa unsur kalium sangat berperan dalam meningkatkan diameter batang tanaman, khususnya dalam peranannya sebagai jaringan yang menghubungkan antara akar dan daun pada proses transpirasi.

Karolina (2018) menjelaskan bahwa POC batang pisang mengandung hormon giberelin dan sitokinin yang berperan dalam pembelahan jaringan tanaman, sehingga meningkatkan volume batang tanaman. Selain itu, menurut Hamzah [4], pemberian pupuk organik cair kepada tanaman yang diaplikasikan dengan cara disiram ke tanah juga sangat membantu tanaman pada proses pertumbuhannya. Hal ini disebabkan karena baik unsur hara makro maupun unsur hara mikro yang dibutuhkan oleh tanaman langsung dapat diserap dan dimanfaatkan oleh tanaman. Unsur hara mikro merupakan hara yang biasanya hanya sedikit tersedia didalam tanah dan sering terjadi persaingan dengan tanaman lain ataupun gulma untuk menyerapnya. Maka dengan diaplikasikan langsung ke tanah akan sangat membantu tanaman proses pertumbuhan.

\section{Panjang Daun Terpanjang}

Hasil pengamatan panjang daun terpanjang tanaman pisang setelah dilakukan analisis ragam menunjukkan bahwa secara interaksi maupun pengaruh utama pemberian NPK Grower dan POC bonggol pisang memberikan pengaruh nyata terhadap panjang daun tanaman pisang. Rata-rata hasil pengamatan panjang daun tanaman pisang setelah dilakukan uji BNJ pada taraf 5\% dapat dilihat pada Tabel 6 .

Data pada tabel 6 menunjukkan bahwa secara interaksi NPK Grower dan POC bonggol pisang memberikan pengaruh yang berbeda nyata terhadap panjang daun tanaman pisang. Perlakuan NPK Grower $45 \mathrm{~g} /$ tanaman dan dosis POC bonggol pisang $450 \mathrm{ml} / \mathrm{l}$ air 
(G3P3) memberikan panjang daun terpanjang yaitu $62,50 \mathrm{~cm}$ namun tidak berbeda nyata dengan perlakuan G3P2 dan G2P3 dan berbeda nyata dengan perlakuan lainnya.

Tabel 6. Rata-rata panjang daun bibit pisang dengan perlakuan NPK Grower dan POC bonggol pisang $(\mathrm{cm})$

\begin{tabular}{|c|c|c|c|c|c|}
\hline \multirow{2}{*}{$\begin{array}{c}\text { NPK Grower } \\
(\mathrm{g} / \operatorname{tanaman})(\mathrm{G})\end{array}$} & \multicolumn{4}{|c|}{ POC Bonggol Pisang (ml/l air) (P) } & \multirow{2}{*}{ Rerata } \\
\hline & $0(\mathrm{P} 0)$ & $150(\mathrm{P} 1)$ & $300(\mathrm{P} 2)$ & $450(\mathrm{P} 3)$ & \\
\hline 0 (G0) & $30,28 \mathrm{f}$ & $33,67 \mathrm{ef}$ & $36,33 \mathrm{def}$ & $38,67 \mathrm{def}$ & $34,74 \mathrm{c}$ \\
\hline 15 (G1) & 33,67 ef & 37,33 def & $38,83 \mathrm{def}$ & $40,17 \mathrm{cde}$ & $37,50 \mathrm{c}$ \\
\hline $30(\mathrm{G} 2)$ & 35,00 ef & $39,50 \mathrm{def}$ & $49,17 \mathrm{bcd}$ & $56,00 \mathrm{abc}$ & $44,92 \mathrm{~b}$ \\
\hline 45 (G3) & $39,33 \mathrm{def}$ & $43,50 \mathrm{def}$ & $57,50 \mathrm{ab}$ & $62,50 \mathrm{a}$ & $50,71 \mathrm{a}$ \\
\hline Rerata & $5,88 \mathrm{~b}$ & $6,08 \mathrm{~b}$ & $7,08 \mathrm{a}$ & 7,46 a & \\
\hline
\end{tabular}

Keterangan: angka-angka yang diikuti huruf yang tidak sama pada baris dan kolom yang sama berbeda nyata menurut BNJ pada taraf $5 \%$.

Kombinasi perlakuan NPK Grower dengan dosis 30 atau $45 \mathrm{~g} / \operatorname{tanaman}(\mathrm{G} 2$ dan G3) dan POC bonggol pisang $450 \mathrm{ml} / \mathrm{l}$ air (G3) memberikan rata panjang daun pisang yang lebih tinggi dikarenakan dapat menyuplai asupan hara yang cukup. Peran bahan organik yang tersedia dalam POC bonggol pisang dapat memperbaiki sifat fisik, kimia dan biologi tanah, membuat tanah gembur, dan akar tanaman dapat berkembang secara normal. Sistem perakaran yang baik dapat mengaktifkan penyerapan unsur hara, membuat metabolisme cepat berkembang secara normal, membuat tanaman tumbuh lebih cepat, dan menambah jumlah daun. Peningkatan ini juga dipengaruhi dari pemberian pupuk NPK Grower dimana nitrogen mempengaruhi pembentukan sel-sel baru, unsur $\mathrm{P}$ mengaktifkan enzim selama fotosintesis, dan $\mathrm{K}$ mempengaruhi perkembangan meristem, sehingga mempengaruhi panjang dan lebar daun.

\section{Lebar Daun Terlebar}

Hasil pengamatan lebar daun terlebar tanaman pisang setelah dilakukan analisis ragam bahwa secara interaksi maupun faktor utama NPK Grower dan POC Bonggol pisang memberikan pengaruh nyata terhadap lebar daun tanaman pisang. Rata-rata hasil pengamatan lebar daun tanaman pisang setelah dilakukan uji BNJ pada taraf $5 \%$ dapat dilihat pada Tabel 7.

Data pada tabel 7 menunjukkan bahwa secara interaksi NPK Grower dan POC bonggol pisang memberikan pengaruh yang berbeda nyata terhadap lebar daun tanaman pisang. Perlakuan NPK Grower $45 \mathrm{~g} /$ tanaman dan dosis POC bonggol pisang $450 \mathrm{ml} / 1$ air (G3P3) menghasilkan lebar daun tanaman terlebar yaitu $23,50 \mathrm{~cm}$ namun tidak berbeda nyata dengan perlakuan G3P2, G2P3, G2P2 dan G1P2 tetapi berbeda nyata dengan perlakuan lainnya.

Tabel 7. Rata-rata panjang daun bibit pisang dengan perlakuan NPK Grower dan POC bonggol pisang $(\mathrm{cm})$

\begin{tabular}{|c|c|c|c|c|c|}
\hline \multirow{2}{*}{$\begin{array}{c}\text { NPK Grower } \\
\text { (g/tanaman) }(\mathrm{G})\end{array}$} & \multicolumn{4}{|c|}{ POC Bonggol Pisang (ml/l air) (P) } & \multirow{2}{*}{ Rerata } \\
\hline & $0(\mathrm{P} 0)$ & $150(\mathrm{P} 1)$ & $300(\mathrm{P} 2)$ & $450(\mathrm{P} 3)$ & \\
\hline $0(\mathrm{G} 0)$ & $12,50 \mathrm{e}$ & $14,83 \mathrm{de}$ & $16,00 \mathrm{~b}-\mathrm{e}$ & $17,00 \mathrm{de}$ & $15,08 \mathrm{c}$ \\
\hline $15(\mathrm{G} 1)$ & $15,83 \mathrm{de}$ & 16,50 a-e & $17,50 \mathrm{a}-\mathrm{d}$ & 17,83 cde & $16,92 \mathrm{bc}$ \\
\hline $30(\mathrm{G} 2)$ & $18,00 \mathrm{~b}-\mathrm{e}$ & $17,00 \mathrm{~b}-\mathrm{e}$ & 18,33 a-e & $22,92 \mathrm{abc}$ & $19,06 \mathrm{ab}$ \\
\hline $45(\mathrm{G} 3)$ & 18,83 a-e & $20,83 \mathrm{~b}-\mathrm{e}$ & $25,17 \mathrm{ab}$ & $23,50 \mathrm{a}$ & $22,08 \mathrm{a}$ \\
\hline Rerata & $16,29 \mathrm{~b}$ & $17,29 \mathrm{~b}$ & $19,25 \mathrm{a}$ & $20,31 \mathrm{a}$ & \\
\hline
\end{tabular}

Keterangan: angka-angka yang diikuti huruf yang tidak sama pada baris dan kolom yang sama berbeda nyata menurut BNJ pada taraf $5 \%$.

Interaksi perlakuan NPK Grower dan POC Bonggol pisang berpengaruh pada lebar daun tanaman pisang. NPK Grower memiliki unsur hara yang yang sangat dibutuhkan tanaman seperti $\mathrm{N}, \mathrm{P}$ dan $\mathrm{K}$. Unsur hara $\mathrm{N}$ memiliki peranan yang penting yaitu $\mathrm{N}$ pada proses pertumbuhan vegetatif tanaman, berperan besar dalam perpanjangan sel tanaman kemudian berperan dalam terbentuknya jaringan dan organ tanaman. Unsur $\mathrm{P}$ juga memiliki peran dalam proses fotosintesis. Unsur P memiliki fungsi sebagai penyedia energi ATP yang digunakan untuk 
proses metabolisme. Sehingga tanpa adanya ATP maka proses metabolisme tidak akan berjalan, termasuk fotosintesis (Oktavianti dan Koesriharti, 2019). Kemudian dipadukan dengan POC bonggol pisang yang merupakan pupuk organik yang memperbaiki sifat fisika, kimia dan biologi tanah sehingga dapat mendukung baiknya pertumbuhan akar. Dengan baiknya kualitas tanah dan pertumbuhan akar maka penyerapan unsur hara yang disumbangkan NPK Grower akan baik pula sehingga dapat melancarkan proses metabolisme tanaman yang berpengaruh pada lebar daun tanaman pisang kepok.

\section{KESIMPULAN}

Berdasarkan hasil penelitian yang telah dilakukan dapat disimpulkan bahwa:

1. Pengaruh interaksi NPK Grower dan POC bonggol pisang memberikan pengaruh yang nyata terhadap parameter tinggi tanaman, jumlah daun, lilit batang, panjang daun terpanjang dan lebar daun terlebar. Perlakuan terbaik adalah dengan dosis NPK Grower $45 \mathrm{~g} /$ tanaman dan POC bonggol pisang $30 \%$ (300 ml/l air) (G3P2).

2. Pengaruh utama NPK Grower nyata terhadap semua parameter. Perlakuan terbaik adalah dengan dosis $45 \mathrm{~g} /$ tanaman (G3).

3. Pengaruh utama POC bonggol pisang nyata terhadap semua parameter. Perlakuan terbaik POC bonggol pisang adalah dengan dosis $30 \%$ (300 ml/l air) (P2).

\section{DAFTAR PUSTAKA}

Anonim. 2015. Pupuk NPK Grower. Online pada:

https://distributorpupuksite.wordpress. com/tag/pupuk-NPK-grower/, Diakses tanggal 23 Februari 2021.

Asmarawati, M dan A. Bahrum. 2011. Pengaruh Rooton F Dan Atonik Terhadap Pertumbuhan Bibit Pisang (Musa paradisiacu L.) Pada Beberapa Media Tanam. Jurnal AgroUPY. 3(1):21-29.

Badan Pusat Statistik. 2018. Statistik Tanaman Buah-buahan dan Sayuran Tahunan Indonesia 2018. Diakses online dari: http://bps.go.id/ diakses Tanggal 13

Desember 2020

Buntoro, B. H, R. Rogomulyo, S. Trisnowati. 2014. Pengaruh takaran pupuk kandang dan intensitas cahaya terhadap pertumbuhan dan hasil temu putih (Curcuma zedoaria L.). Vegetika. 3 (4) : 29-39.

Karolina, W. 2018. Pengaruh Pupuk Organik Cair Bonggol Pisang Kepok (Musa acuminate L) terhadap Pertumbuhan Tanaman Okra Merah (Abelmoschus caillei). Skripsi. Universitas. Sanata Darma. Yogyakarta.

Komalasari, O. dan F. Koes. 2009. Pengaruh Kualitas Biji Pada Berbagai Taraf Pemupukan Nitrogen Terhadap Vigor Benih Jagung. Prosiding Seminar Nasional Serelia 2009. Maros, 29 Juli 2009.

Kusumawati, A. 2015. Analisa Karakteristik Pupuk Kompos Berbahan Batang Pisang. Prosiding Seminar Nasional Universitas PGRI Yogyakarta.

Laginda, YS. M. Darmawan. I.T. Syah. 2017. Aplikasi Pupuk Organik Cair Berbahan Dasar Batang Pisang Terhadap Pertumbuhan dan Produksi Tanaman Tomat (Lycopersicum esculentum Mill.). Jurnal Galung Tropik. 6(2):81-92

Lesilolo, M.K. 2012. Studi Pemupukan Fosfat Terhadap Terhadap Viabilitas Dan Vigor Benih Jagung (Zea mays L.) Varietas Hulaliu. Jurnal Agrologia 1(2): 119-125.

Lindung. 2014. Teknologi aplikasi zat pengatur tumbuh. balai pelatihan pertanian.Jambi.

http://www.bppjambi.info/newspopup. asp?id=603. Diunduh.Juli 2021

Munawar, A. 2011. Kesuburan Tanah dan Nutrisi Tanaman. IPB Press. Bogor.

Oktavianti, L.D. dan Koesriharti. 2019. Pengaruh Pupuk Anorganik pada Pertumbuhan dan Hasil Tanaman Kol Bunga (Brassica oleracea L. var. botrytis L.). Jurnal Produksi Tanaman. 7(12):2315-2322.

Puspadewi, S., W. Sutarti dan Kusumiyati. 2016. Pengaruh konsentrasi pupuk organik cair (POC) dan dosis pupuk N, $\mathrm{P}, \mathrm{K}$ terhadap pertumbuhan dan hasil tanaman jagung manis (Zea mays L. 
var Rugosa Bonaf) kultivar Talenta. Jurnal Kultivasi. 15(3):208-216.

Satria, N. , Wardati , M. A. Khoiri. 2015. Pengaruh Pemberian Kompos Tandan Kosong Kelapa Sawit Dan Pupuk NPK Terhadap Pertumbuhan Bibit Tanaman Gaharu (Aquilaria malaccencis). JOM Faperta 2(1)

Setianingsih, R. 2009. Kajian Pemanfaatan Pupuk Organik Cair Mikro Organisme Lokal (MOL) dalam Priming, Umur Bibit dan Peningkatan Daya Hasil Tanaman Padi (Oryza sativa L.) Uji Coba Penerapan System Of Rice Intensification (SRI). BPSB Propinsi DIY, Yogyakarta.

Setyorini, T., R. M. Hartati. A. L. Damanik. 2020. Pertumbuhan Bibit Kelapa Sawit di Pre Nursery Dengan Pemberian Pupuk Organik Cair (Kulit Pisang) dan Pupuk NPK. Agritrop, 18 (1): 98 106.
Suhastyo, A.A. 2011. Studi Mikrobiologi dan Sifat Kimia Mikroorganisme Local yang Digunakan Pada Budidaya Padi Metode SRI (System Of Rice Intensification). Tesis. Institut Pertanian Bogor, Bogor.

Sumarni, N., R. Rosliani, dan A.S. Duriat. 2010. Pengelolaan Fisik, Kimia, dan Biologi Tanah untuk Meningkatkan Kesuburan Lahan dan Hasil Cabai Merah. J. Hort. 20(2):130-137

Wahida dan N.L.S. Suryaninsih. 2016. Analisis kandungan unsur hara pupuk organik cair dari limbah rumah tangga di Kabupaten Merauke. Jurnal Agricola, 6 (1): 23-30.

Yunita, R. 2011. Pengaruh Pemberian Urine Sapi, Air Kelapa dan Rootone F Terhadap Pertumbuhan Setek Tanaman Markisa (Passiflora edulis var. flavicarpa). Tugas Akhir. Universitas Andalas. Padang. 
